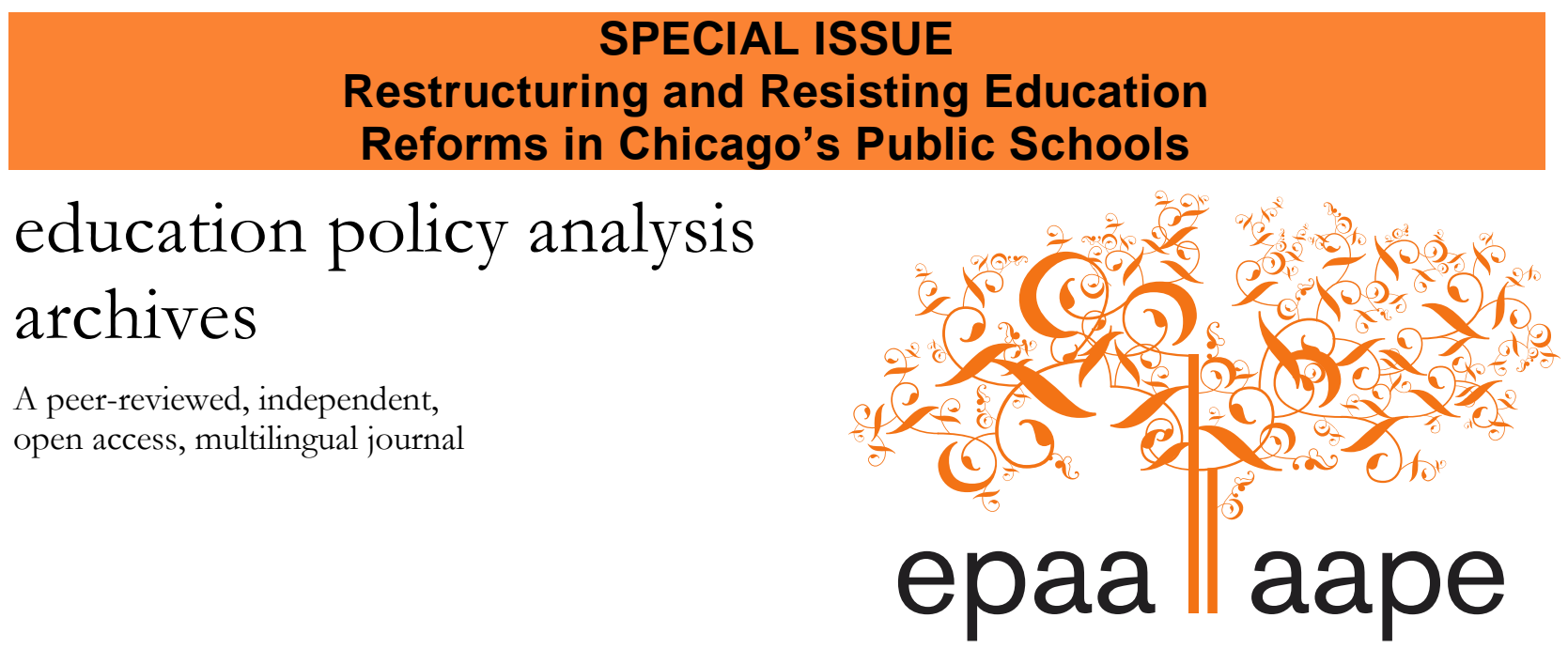

Arizona State University

\title{
Introduction to the Special Issue: Restructuring and Resisting Education Reforms in Chicago's Public Schools
}

\author{
Rhoda Rae Gutierrez. \\ \& \\ Federico R. Waitoller \\ University of Illinois at Chicago \\ United States
}

Citation: Gutierrez, R., \& Waitoller, F. R. (2017). Introduction to the special issue: Restructuring and resisting education reforms in Chicago's public schools. Education Policy Analysis Archives, 24(53). http://dx.doi.org/10.14507/epaa.25.3061 This article is part of EPAA/AAPE's Special Issue on Restructuring and Resisting Education Reforms in Chicago's Public Schools, Guest Edited by Federico Waitoller and Rhoda Rae Gutierrez.

Abstract: In this paper, guest editors Gutierrez and Waitoller introduce the special issue, Restructuring and Resisting Education Reforms in Chicago's Public Schools. As a pioneer of neoliberal education reforms, the city of Chicago and its public school system offers a rich context for critical policy scholarship on the dialectic between education restructuring and community resistance against these reforms. First, the authors contextualize Chicago education reforms within the larger neoliberal project by providing an overview of the policies driving the closures of traditional public schools and expansion of charter schools and other privatization efforts that the contributors to this special issue examine. The 
authors also address the co-constitutive nature of race and neoliberalism in education policy, and the disproportionate impact these policies have on low-income communities of color. Next, the authors discuss the significance of this collection of papers for educational policy analysis and call for more research that situates examinations of urban educational reforms in their specific socio-historical, political, and economic contexts. The paper concludes with a summary of the articles included in the special issue.

Keywords: neoliberalism; education policy; race; critical scholarship

Introducción a la edición especial: Reestructuración y resistiendo las reformas educativas en las escuelas públicas de Chicago

Resumen: Los editores invitados Gutiérrez y Waitoller introducen la edición especial, Restructuración y Resistiendo las Reformas Educativas en las Escuelas Públicas de Chicago, en este artículo. Como pionera de las reformas educativas neoliberales, la ciudad de Chicago y su sistema de escuelas públicas ofrecen un contexto detallado para la investigación de política crítica sobre la filosofía entre la reestructuración de la educación y la resistencia de la comunidad contra estas reformas. Primero, los autores contextualizan las reformas de educación en Chicago dentro del contexto neoliberal más amplio, proveyendo una descripción general de las pólizas que causan los cierres de las escuelas públicas tradicionales y la expansión de las escuelas chárter y otros esfuerzos de privatización que los contribuyentes de esta edición especial examinan. Los autores también abordan el carácter co-constitutivo de la raza y el neoliberalismo en la póliza educativa y el impacto desproporcionado de estas pólizas sobre las comunidades de bajos ingresos de color. Después, los autores discuten la importancia de esta colección de artículos para el análisis de la póliza educativa y exigen que más investigaciones ubican los exámenes de las reformas educativas urbanas en sus contextos específicos socio-históricos, políticos y económicos. El artículo concluye con un resumen de los artículos incluidos en la edición especial.

Palabras clave: neoliberalismo; póliza educativa; raza; investigación crítica

\section{Introdução à edição especial: Reestruturação e resistindo a reformas educacion ais em escolas públicas em Chicago}

Resumo: Os editores convidados Waitoller e Gutierrez introduzir a edição especial, reestruturação e Resistindo reformas educacionais no escolas públicas de Chicago, neste artigo. Como um pioneiro das reformas educativas neoliberais, a cidade de Chicago e seu sistema escolar público oferecem uma investigação detalhada sobre a filosofia política crítica entre reestruturação do ensino e da resistência da comunidade contra estes contexto reformas. Primeiro, os autores contextualizam reformas educacionais em Chicago no contexto neoliberal mais ampla, fornecendo uma visão geral das políticas que causam fechamento de escolas públicas tradicionais e expandir as escolas charter e outros esforços de privatização que os contribuintes esta edição especial examinado. Os autores também abordam o caráter coconstitutiva da corrida e neoliberalismo na política educacional eo impacto desproporcional dessas políticas em comunidades de baixa renda de cor. Em seguida, os autores discutem a importância desta coleção de artigos para análise da política educacional e exigem mais investigação localizada exames reformas educacionais urbanas em seus contextos sócio históricos, políticos e económicos específicos. O artigo conclui com um resumo dos artigos incluídos na edição especial.

Palavras-chave: neoliberalismo; política educacional; raça; pesquisa crítica 


\section{Restructuring and Resisting Education Reforms in Chicago's Public Schools}

On February 7, 2017, the United States Senate confirmed Betsy DeVos as Secretary of the Department of Education, an unprecedented cabinet appointment in many respects. DeVos, a billionaire heiress, ironically has no personal or professional experience in public education. She is a fervent proponent of education reforms that aim to marketize and privatize public education, backing school vouchers and charter schools in her home state of Michigan. Her senate confirmation was extraordinary. DeVos became the first cabinet nominee in U.S. history to require the tie-breaking vote of the vice president when a favorable senate majority could not be reached, as she demonstrated little understanding of federal education policy during confirmation hearings. Her nomination faced massive public resistance. Across the country, grassroots organizations led by people of color, teachers unions and other proponents of public education mounted intense opposition to her nomination (see Journey for Justice Alliance, www.j4jalliance.com; Alliance to Reclaim Our Schools, www.reclaimourschools.org; Huetteman \& Alcindor, 2017). DeVos' appointment, however, does not signal a deviation from the neoliberal agendas of past administrations. Neoliberal policies regulating education and other social services have been orchestrated and implemented by both Democrats and Republicans since the late 1970s, even by liberals' coveted president Barack Obama. Yet, DeVos' rise to the top education post in the country indicates an intensification of the neoliberal assault on public education (Watkins, 2012).

The contentious selection of Betsy DeVos as education secretary underscores the importance of this special EPAA issue. The following articles tackle the dialectic of neoliberal education restructuring and grassroots resistance. Market-driven policies and undemocratic governance, key features of neoliberal reforms, have targeted urban school districts across the country, disproportionately impacting low-income communities of color. These reforms create conditions for neighborhood school closings and privatization schemes, and transform the purpose of public education away from its social democratic promise toward human capital development and global economic competitiveness. Communities of color most affected by these education reforms are leading the resistance to these reforms and are key to reimagining a more just and equitable public education for all. Chicago, a pioneer of neoliberal education reforms, is an important site to study the interplay between restructuring and resistance to raise critical questions for future research and action.

\section{Neoliberal Education Reforms and the Significance of the Chicago Case}

One of the most contentious battles over public education is being waged in Chicago. Because the city has served as a testing-ground for neoliberal education reforms, a close study of the Chicago case can provide insight for other cities facing similar reforms. Under former Mayor Richard M. Daley in the 1990s, Chicago Public Schools (CPS) came under mayoral control and introduced high-stakes testing and accountability policies that ranked, sorted and labelled schools. These policies informed George W. Bush's 2001 No Child Left Behind Act (Lipman, 2004), which instituted a national regime of testing, standards and accountability measures that has become normalized in U.S. education policy. They also laid the groundwork for Daley's signature reform Renaissance 2010 (Ren10), which was launched in 2004 and claimed would improve schools by closing "failing" neighborhood schools and providing more school choice by opening charter schools (publicly funded but privately managed schools) (Lipman \& Haines, 2007). Ren10 paved the way for the historic school closings of May 2013, when Mayor Rahm Emanuel's appointed CPS Board of Education approved the closure of 50 public schools to "right size" the district amidst an 
ongoing budget crisis. Since 2000, more than 130 schools have been closed which have disproportionately impacted African American communities (Weber, Farmer, \& Donoghue, 2017). This racialized neoliberal education restructuring under the guise of education reform has hit dozens of cities across the country (Journey for Justice, 2014).

As the articles in this special issue discuss, neoliberalism is a dominant political-economic and social paradigm shaping education policy. Neoliberalism promises society's well-being can be best achieved if free market principles govern all spheres of life. Instead, free-market policies have caused severe damage to communities throughout the world, most recently related to the 2008 global economic crisis- from the debt crisis in Greece to the housing and banking collapse in the U.S. to increasing education privatization and skyrocketing student debt in Chile. Neoliberalism is however successfully re-distributing the world's wealth into the hands of a few elites (Harvey, 2005). Last year, 62 individuals held half of the world's wealth; this year, this wealth is owned by eight men (Oxfam, 2017). Despite neoliberal theory's push for "small government," the state plays a central role in pushing the neoliberal project (thus the importance of studying state institutions like education). The "invisible hand" of the market is rather the state's hand in creating conditions to foster market growth and capital accumulation while withdrawing from its core responsibilities to the public good. This includes opening public institutions to privatization and profit-making, what Harvey calls "accumulation by dispossession" (Harvey, 2005).

Over the past two decades, public education has been increasingly privatized. This has been largely accomplished through the expansion of charter schools and closing of traditional public schools. Furthermore, a kind of piecemeal privatization has been eroding public education through private contracts for food service, nursing, and janitorial work for example (see Fitzpatrick, 2017; Perez, 2016). These district-level reforms have undermined unions, which are powerful institutional barriers to privatization, and are linked to gentrification and the restructuring of city economies for finance and real estate development (Lipman 2011) or other niche markets (Pedroni, 2011) where local school systems are driven more and more to produce workers that meet market needs over community needs. Although the majority of U.S. schools are traditional public schools, Secretary DeVos is moving to shift significant federal dollars from these schools to charters and other "choice" programs (Brown, Strauss, \& Douglas-Gabriel, 2017), which will put education privatization into overdrive. CPS has experienced some of the most intense education restructuring in the country, evidenced by the Chicago Board of Education's unprecedented closure of 50 public schools in 2013. If implemented, the education secretary's agenda will accelerate these market-driven transformations in CPS and exacerbate the impacts to communities of color across the city.

Race is central to education restructuring (Picower \& Mayorga, 2015) (and dis/ability, as Waitoller and Super argue in their article). As social problems rise with the decline of social programs, neoliberalism calls for "new modes of 'social' and penal policy-making, concerned specifically with the aggressive reregulation, disciplining, and containment of those marginalized or dispossessed" (Peck \& Tickell, 2002, p. 389), rendering largely poor communities of color as disposable (Wacquant, 2014). What's significant in this special issue is the authors center the experiences of those rendered "disposable" in Chicago's public education system in their analyses. Aviles and Heybach address the implications of the hyper-instability homeless students of color faced during the 2013 school closings through an intersectional analysis of white supremacy and neoliberalism. Waitoller and Super unpack the complex and difficult decisions Black and Latinx parents of students with dis/abilities must make as they navigate Chicago's school choice system and urban restructuring. Jankov and Caref detail the intensified segregation of Black students and Black teachers under education restructuring and discuss the implications of this trend reflecting on Chicago's long history of racial segregation. 
Notably, those who are rendered "disposable," the people most affected by these education reforms, are leading the strongest opposition to these market-based policies: parents, students, and teachers (and their unions). As Lipman argues in the opening article, resistance to education policy in Chicago is an expression of the rejection of neoliberal policies to remake the city for capital accumulation [...] and to simply abandon, contain, or drive out those whose lives do not matter and are, in fact, disposable in a context of corporate hegemony, elite consumption, and whiteness.

As Lipman's discussion of the dialectic of restructuring and resistance shows, communities of color cannot simply appeal to the sensibilities of policymakers to support a pro-people's agenda (for an example, see her account of the Dyett Hunger Strike and the community-union push for an elected school board). A people's policy agenda—such as living wages, affordable and accessible housing, quality healthcare, and equitable educational opportunities - cannot advance without grassroots struggle and the leadership and "moral compass" of Black and Latinx community organizations.

In addition, as new or repackaged privatization schemes are introduced as silver bullets to public education problems, it is imperative that we unpack the assumptions surrounding the claims of success of these market reforms as Saltman does in his article. The saturation of market logics and language across so many areas of our lives, including the non-economic, obscure the intersecting socio-historical, political and economic structures that shape education inequities-this needs to be more deeply understood to advance non-reformist reforms, "reforms that alter and better the present conditions and can lead to serious structural changes" (Apple, 1995, p. 120). As a hegemonic discourse, neoliberalism limits our social imaginaries as to "how things might be 'otherwise'—different from the way they are now" (Rizvi \& Lingard, 2010, p. 8). Therefore, as Vaughan and Gutierrez argue in their paper, the hopes and desires of the people most affected by neoliberal education policies can provide the foundation for reimagining more just and equitable schools.

After years of market-based reforms, skipped pension payments, and unscrupulous bond deals under an unelected school board, Chicago Public Schools is currently facing what seems to be an insurmountable fiscal crisis. This crisis could be a tipping point in the struggle over Chicago public education. As Rahm Emanuel (2008) famously said, "You never want a serious crisis to go to waste, and what I mean by that is an opportunity to do things that you think you could not do before." City and school leaders have seized this crisis to make massive cuts to individual school budgets, special education and other critical school programs, and teacher pay (through unpaid furlough days). Grassroots groups, unions and allies are challenging this austerity agenda with proposals for revenue solutions (including the redirction of tax increment financing surpluses and resinstatement of the corporate head tax), an elected representative school board, and sustainable community schools to address the needs of each neighborhood. Chicago is an epicenter of community-union resistance to neoliberal education reforms (Gutstein \& Lipman, 2013). These coalitions are making connections across issues and neighborhoods and pushing for a more just vision for public education in Chicago. As Fabricant and Fine (2013) assert, the spark and power for such change must come from the overlapping of communities embroiled in the consequences of neglect and ever-harsher Social Darwinist policies working in collaboration with allies who recognize shared fateseducator networks; unions across sectors; youth movements across neighborhoods. (p. 153) 
Researchers should (and do) play a role in this growing movement for education and social justice. Certainly, as Lubienski argues in the closing article, researchers need to use accessible language to better persuade policymakers to support research-based reforms that improve educational opportunities. Furthermore, this collection of papers emphasizes that to advance education equity, research must name and unpack the socio-historical and political-economic structures that are the foundation for the unjust conditions in our education system and our cities. It is the experiences and desires of the students, families and communities who face and also resist these conditions every day that must be at the heart of our work. We hope the collection of papers in this EPAA special issue contributes to this spark for change that communities have ignited by identifying "overlapping" community experiences and ruptures in the racialized neoliberal education reforms that gave rise to this special EPAA issue.

\section{Reframing Policy Analysis}

There is a plethora of literature on the effects of neoliberal policies on public education such as school choice, accountability, and privatization of public schools. Yet, prior literature on neoliberal school reform has relied heavily on quantifiable indicators (e.g., test scores, dropout rates, enrollment, demographic composition). These works have evaluated the impact of education reforms by comparing how well students perform academically between school options (e.g., charter school, traditional school, and magnet schools) or between students whose school closed and those whose school stayed open. Charter schools have been the fastest growing sector within these reforms and have taken the spotlight of most research on school reform. In terms of academic outcomes, research on charter schools have shown mixed and inconclusive effects (Berends, 2015; Furgeson et al. 2012; Gleason et al. 2010). Other studies, though a smaller number, have found that students attending charter schools are more likely to graduate than those attending traditional schools (e.g., Booker et al, 2011). These studies align with much of the school choice narrative that focuses on parents' lack of quality educational choice, where quantitative academic achievement indicators are proxies for school quality.

As Dumas and Anderson (2014) remind us, this dominant paradigm of educational policy requires that research indicate how policies affect academic achievement, service delivery, and the efficiency of institutions; show proof of "best practices"; and evaluate the outcomes of policy based on cost-benefit analysis. While this type of research aims to achieve high level of rigor through randomized trials or quasi-experimental designs, they decontextualize and dehistoricize the issue at stake (Erickson \& Gutierrez, 2002). As a result, the institutional, structural and cultural aspects of the problem are dismissed. Further, using 'neutral' measures of policy success comes at the expense of being color evasive (Annamma, Jackson, \& Morrison, 2016). That is, this research has evaded the examination of the structural, ideological, and discursive power of race and dis/ability, particularly when they intersect. The problem with color evasiveness is that it locates the problem within individuals of color; it assumes that the market is neutral and treats all equally, thus race can be discounted (Annamma et al., 2016; Gotanda, 1991). This is important, as once the problem is defined and explained with a set of explanations, other ways to understand the problem are undervalued and under-researched (Edelman, 1987; Smith, 2004).

Further, policies influence much more than educational outcomes. They influence practices, people's beliefs and attitudes, community and institutional dynamics, and a whole range of human experiences and relationships. Policies are not implemented in a blank slate, but amid evolving forms of racism, classism and ableism. Thus, quantifiable academic outcomes are only a small piece of a historically evolving puzzle. 
The papers in the present special issue complicate this narrow and simplistic framing. They build upon the work of critical scholars in education (e.g., Buras, 2015; Picower \& Mayorga, 2015; Lipman, 2011; Stovall, 2013) to contextualize such reforms within the history of racial struggles (and dis/ability as Waitoller and Super argue in their paper) for educational justice and the ongoing and increasing neoliberal privatization of the education sector. Thus, the papers in this special issue expand on the notion of 'relevance', recognizing that the influence of these reforms is far from being direct, but rather diffuse and elusive to direct causation, and that their influence is most extensive at the stage of problem definition (Dumas \& Anderson, 2014). In this sense, the papers presented in this special issue are a form of resistance to the neoliberal dismantling of public education.

\section{Content of the Special Issue}

The papers in this special issue examine the complex and interacting consequences of and contestations to neoliberal reforms. In the first paper, Pauline Lipman draws from her experience as activist-scholar to immerse the reader in the historical, political, economic, and educational context of Chicago. Her paper examines the relationship between neoliberalism, racism, and educational policy in the third largest city in the US. Importantly, her paper examines the dialectics between the neoliberal restructuring of urban education and the resistance of grassroots organizations. Locating this dialectic in race and class struggles locally and globally, she argues that what is at stake is the fight for the soul of public education and the city.

Federico Waitoller and Gia Super present a qualitative study that complicates simplistic notions of school choice, particularly for Black and Latinx parents of student with dis/abilities. The authors examine how these parents engage with school choice within the context of urban spatial restructuring. Their findings demonstrate how parents of students with dis/abilities engage in the politics of desperation (Stovall, 2013). Further, the study examines how parents' engagement with the politics of desperation is tightly linked to processes of urban spatial restructuring such as creative destruction (Theodore \& Brenner, 2002) and uneven geographical development (Harvey, 2006). The paper compels the readers to account for the intersections of race and dis/ability when studying and understanding school choice reforms.

Pavlyn Jankov and Carol Caref of the Chicago Teachers Union (CTU) examine the historical segregation of Black students in CPS and the impact of corporate reforms on segregation patterns. Unique to this paper is the analysis not only of student segregation but also of the segregation of Black teachers, what the authors call "dual segregation." The authors conclude that corporate reforms such as closing traditional public schools and opening charter schools have deepened dual segregation and have severe implications for equitable resource allocation across CPS.

Kelly Vaughan and Rhoda Rae Gutierrez's paper examines the history of the purpose of public education and narratives of parents affected by the historic 2013 school closings. Their analysis indicates that despite neoliberal efforts to frame education and students as commodities and parents as consumers, parents affected by school closings see neighborhood schools as community anchors and had a more democratic vision of public schools. Their paper points out that at the root of the dialectics between restructuring and resisting educational reforms is a battle to frame and define the purpose of public education.

Anne Aviles and Jessica Heybach's paper examines an alarming silence in school reform research: students of color experiencing housing instability. The paper provides the legal and social context of homeless students. Through an intersectional analysis of Critical Race Theory and neoliberalism, the authors discuss how these students are particularly vulnerable to school closings 
that exacerbate instability in their lives. They identify that challenging white supremacy and "slow violence" are key to creating equitable education policy for homeless students and call on researchers and policy makers to attend to the unique circumstance of these students.

Kenneth Saltman examines the core assumptions of Pay for Success (PfS), a financing practice that has quietly gained momentum and has made its way to the new reauthorization of the Elementary and Secondary Education Act, named Every Student Succeeds Act. He debunks the claims favoring PfS on the grounds of market discipline, cost savings for districts, transferring the risk of failure, and corporate responsibility. Saltman concludes that PfS "is neither innovative nor necessary but is rather a technique for rich investors to skim money out of public service provision, a hijacking of public governance, and misrepresentation of the corporate fleecing of the public sector as corporate social responsibility."

In the final paper, Christopher Lubienski discusses overarching themes of the special issue. Lubienski's final discussion highlights that neoliberal reforms do not organically emerge. They are the result of strategic efforts by corporate and political elites that experiment in working class and racial minority communities. These reforms, Lubienski reminds us, always face resistance as illustrated in the papers of this special issue. In addition, this final paper provides a word of caution about how we use language in critical scholarship and the problem of creating echo chambers in our research, preaching to the choir. Lubienski offers recommendations for critical scholarship to better persuade policy makers.

In sum, the papers in this special issue respond to Ball's (Avelar, 2016) call in Education Policy Analysis Archives to capture the "disorder, the messiness, the incoherence of the political life of schools, and concomitant processes of struggle, conflict and compromise" (p. 4). They do not serve as a conclusive set of findings but rather a call to researchers, urging them to further interrogate neoliberal policies and their interconnections with race, class, and dis/ability. The papers underscore the significance of accounting for the socio-historical and political contexts of urban centers when examining educational reforms. It is in this kind of analysis that race, class and dis/ability become dynamic explanatory structures rather than static demographic variables.

\section{Acknowledgements}

We want to thank our stellar team of reviewers and the editors of Education Policy Analysis Archives who helped us to improve and ensure the quality of this special issue. The second author acknowledges the support of the Institute for Research on Race and Public Policy at the University of Illinois at Chicago.

\section{References}

Apple, M. (1995). Education and power (2nd ed.). New York: Routledge.

Avelar, M. (2016). Interview with Stephen J. Ball: Analyzing his contribution to education policy research. Archivos Analíticos de Políticas Educativas, 24(24). http://dx.doi.org/10.14507/epaa.24.2368

Berends, M. (2015). Sociology and School Choice: What We Know After Two Decades of Charter Schools. Annual Review of Sociology, 41(1), 159-180. doi: 10.1146/annurev-soc-073014-112340

Booker, K., Sass, T., Gill, B., \& Zimmer, R. (2011). The effects of charter high schools on educational attainment. Journal of Labor Economics, 29(2), 377-415. 
Brenner, N., \& Theodore, N. (2002). Cities and the geographies of "actually existing neoliberalism". In N. Brenner, \& N. Theodore (Eds.), Spaces of neoliberalism: Urban restructuring in North America and Western Europe (pp. 2-32). Malden, MA: Blackwell Publishing.

Brown, E., Strauss, V., \& Douglas-Gabriel, D. (2017, May 17). Trump’s first full education budget: Deep cuts to public school programs in pursuit of school choice. The Washington Post. Retrieved from https://www.washingtonpost.com/local/education/trumps-first-fulleducation-budget-deep-cuts-to-public-school-programs-in-pursuit-of-schoolchoice/2017/05/17/2a25a2cc-3a41-11e7-8854$21 \mathrm{f} 359183 \mathrm{e} 8 \mathrm{c} \_$story.html?utm_term $=.0 \mathrm{a} 0 \mathrm{cdd} 2 \mathrm{c} 8 \mathrm{~b} 84$

Buras, K. L. (2015). Charter schools, race, and urban space: Where market meets grassroots resistance. New York: Routledge

Commercial Club of Chicago. (2003). Left behind: Student achievement in Chicago's Public Schools. Retrieved from http://civiccommittee.org/Media/Default/pdf/LEFT_BEHIND.pdf

Dumas, M., \& Anderson, G. (2014). Qualitative research as policy knowledge: Framing policy problems and transforming education from the ground up. Education Policy Analysis Archives, 22, 11. http://dx.doi.org/10.14507/epaa.v22n11.2014

Edelman, M. (1988). Constructing the political spectacle. Chicago: The University of Chicago Press.

Emanuel, R. (2008). Rahm Emanuel speech at the Wall Street Journal CEO Council in Washington, D.C. Retrieved from http://www.wsj.com/video/rahm-emanuel-on-the-opportunities-ofcrisis/3F6B9880-D1FD-492B-9A3D-70DBE8EB9E97.html

Erickson, F., \& Gutierrez, K. (2002). Culture, rigor, and science in educational research. Educational Researcher, 31(8), 21-24

Fabricant, M., \& Fine, M. (2013). The changing politics of education: Privatization and the dispossessed lives left behind. Boulder: Paradigm Publishers.

Fitzpatrick, L. (2017, January 25). CPS to ask Board of Ed for $\$ 535$ for facilities deals. Retrieved from http:// chicago.suntimes.com/politics/cps-to-ask-board-of-ed-for-535m-for-facilitiesdeals /

Furgeson, J., Gill, B., Haimson, J., Killewald, A., McCullough, M., Nichols-Barrer, I., . . Lake, R. (2012). Charter-School Management Organizations: Diverse Strategies and Diverse Student Impacts. University of Washington: Mathematica Policy Research/Center on Reinventing Public Education.

Gill, S. (2003). Power and resistance in the new world order. New York: Palgrave Macmillan.

Gleason, P. M., Clark, M. A., Tuttle, C. C., \& Dwoyer, E. (2010). The Evaluation of Charter School Impacts. Washington, DC: U.S. Department of Education.

Gutstein, E., \& Lipman, P. (2013). The rebirth of the Chicago Teachers Union and possibilities for a counter-hegemonic education movement. Monthly Review, 65(2), 1.

Harvey, D. (2005). A brief history of neoliberalism. Oxford University Press.

Harvey, D. (2006). Spaces of Global Capitalism: Towards a Theory of Uneven Geographical Development. New York: Verso.

Huetteman, E, \& Alcindor, Y. (2017, February 7). Betsy DeVos confirmed as education secretary; Pence breaks tie. The New York Times. Retrieved from https://www.nytimes.com/2017/02/07/us/politics/betsy-devos-education-secretaryconfirmed.html

Journey for Justice Alliance. (2014). Death by a thousand cuts: Racism, school closures, and public school sabotage. Retrieved from https://www.j4jalliance.com/wpcontent/uploads/2014/02/J4JReport-final_05_12_14.pdf 
Lipman, P. (2004). High stakes education: Inequality, globalization, and urban school reform. New York: Routledge.

Lipman, P. (2011). The new political economy of urban education: Neoliberalism, race, and the right to the city. New York: Routledge.

Lipman, P., \& Haines, N. (2007). From accountability to privatization and African American exclusion Chicago's "Renaissance 2010”. Educational Policy, 21(3), 471-502.

Lubienski, C., Scott, J., \& DeBray, E. (2014). The politics of research production, promotion, and utilization in educational policy. Educational Policy, 28(2), 131-144.

Oxfam. (2017). Just 8 men own the same wealth as half the world [Press release]. Retrieved from https://www.oxfam.org/en/pressroom/pressreleases/2017-01-16/just-8-men-own-samewealth-half-world

Peck, J., \& Tickell, A. (2002). Neoliberalizing space. Antipode, 34(3), 380-404.

Pedroni, T. C. (2011). Urban shrinkage as a performance of whiteness: Neoliberal urban restructuring, education, and racial containment in the post-industrial, global niche city. Discourse: Studies in the Cultural Politics of Education, 32(2), 203-215.

Perez, J. (2016, February 23). Chicago Teachers Union says outsourcing nurses bad for students. Retrieved from http://www.chicagotribune.com/news/ct-chicago-school-nursescomplaints-met-0224-20160223-story.html

Picower, B., \& Mayorga, E. (2015). What's race got to do with it? How current school reform policy maintains racial and economic inequality. New York: Peter Lang.

Rizvi, F., \& Lingard, B. (2010). Globalizing education policy. New York: Routledge.

Smith, L. M. (2004). Political spectacle and the fate of American schools. New York: RoutledgeFalmer.

Stovall, D. (2013). Against the politics of desperation: Educational justice, critical race theory, and Chicago school reform. Critical Studies in Education, 54(1), 33-43.

Watkins, W. (2012). The assault on public education: confronting the politics of corporate school reform. New York: Teachers College Press.

Weber, R., Farmer, S., \& Donoghue, M. (2017). Why these schools? Explaining school closures in Chicago, 2000-2013. Retrieved from https://greatcities.uic.edu/2017/01/10/why-these-schoolsexplaining-school-closures-in-chicago-2000-2013/ 


\title{
About the Authors/Guest Editors
}

\section{Rhoda Rae Gutierrez}

University of Illinois at Chicago

rrgutier@uic.edu

Rhoda Rae Gutierrez is a doctoral candidate in Educational Policy Studies at the University of Illinois at Chicago. Her research interests include neoliberal education policy, cultural politics of race, and social justice. She is a researcher with the Collaborative for Equity and Justice in Education and a parent activist.

Federico R. Waitoller

University of Illinois at Chicago

fwaitoll@uic.edu

Dr. Waitoller is an assistant professor in the department of special education at the University of Illinois at Chicago. His research focuses on urban inclusive education. In particular, he examines how neoliberal informed polices, such as top-down accountability, portfolio district models, and school choice converge with inclusive education efforts, and how these initiatives affect Black and Latino students with disabilities. His research also examines teacher learning efforts and pedagogies for inclusive education.

\section{SPECIAL ISSUE Restructuring and Resisting Education Reforms in Chicago's Public Schools education policy analysis archives}

Volume 25 Number $53 \quad$ July 5, 2017

ISSN 1068-2341

\begin{abstract}
@)
SOMERIGHISRESERVED Readers are free to copy, display, and distribute this article, as long as the work is attributed to the author(s) and Education Policy Analysis Archives, it is distributed for noncommercial purposes only, and no alteration or transformation is made in the work. More details of this Creative Commons license are available at http://creativecommons.org/licenses/by-nc-sa/3.0/. All other uses must be approved by the author(s) or EPAA. EPAA is published by the Mary Lou Fulton Institute and Graduate School of Education at Arizona State University Articles are indexed in CIRC (Clasificación Integrada de Revistas Científicas, Spain), DIALNET (Spain), Directory of Open Access Journals, EBSCO Education Research Complete, ERIC, Education Full Text (H.W. Wilson), QUALIS A1 (Brazil), SCImago Journal Rank; SCOPUS, SOCOLAR (China).

Please contribute commentaries at http://epaa.info/wordpress/ and send errata notes to Audrey Amrein-Beardsley at audrey.beardsley@,asu.edu

Join EPAA's Facebook community at https://www.facebook.com/EPAAAAPE and Twitter feed@epaa_aape.
\end{abstract}




\section{education policy analysis archives editorial board}

Lead Editor: Audrey Amrein-Beardsley (Arizona State University)

Editor Consultor: Gustavo E. Fischman (Arizona State University)

Associate Editors: David Carlson, Margarita Jimenez-Silva, Eugene Judson, Mirka Koro-Ljungberg, Scott

Marley, Jeanne M. Powers, Iveta Silova, Maria Teresa Tatto (Arizona State University)

Cristina Alfaro San Diego State

University

Gary Anderson New York

University

Michael W. Apple University of

Wisconsin, Madison

Jeff Bale OISE, University of

Toronto, Canada

Aaron Bevanot SUNY Albany

David C. Berliner Arizona

State University

Henry Braun Boston College

Casey Cobb University of

Connecticut

Arnold Danzig San Jose State

University

Linda Darling-Hammond

Stanford University

Elizabeth H. DeBray University of

Georgia

Chad d'Entremont Rennie Center for Education Research \& Policy

John Diamond University of Wisconsin, Madison

Matthew Di Carlo Albert Shanker Institute

Michael J. Dumas University of California, Berkeley

Kathy Escamilla University of Colorado, Boulder

Melissa Lynn Freeman Adams State College

Rachael Gabriel

University of Connecticut

Amy Garrett Dikkers University of North Carolina, Wilmington

Gene V Glass Arizona

State University
Ronald Glass University of

California, Santa Cruz

Jacob P. K. Gross University of Louisville

Eric M. Haas WestEd

Julian Vasquez Heilig California

State University, Sacramento

Kimberly Kappler Hewitt University of North Carolina Greensboro

Aimee Howley Ohio University

Steve Klees University of Maryland

Jaekyung Lee

SUNY Buffalo

Jessica Nina Lester

Indiana University

Amanda E. Lewis University of Illinois, Chicago

Chad R. Lochmiller Indiana

University

Christopher Lubienski

Indiana University

Sarah Lubienski University of Illinois, Urbana-Champaign

William J. Mathis University of Colorado, Boulder

Michele S. Moses University of Colorado, Boulder

Julianne Moss Deakin

University, Australia

Sharon Nichols University of Texas, San Antonio

Eric Parsons University of

Missouri-Columbia

Susan L. Robertson Bristol

University, UK

Gloria M. Rodriguez

University of California, Davis
R. Anthony Rolle University of Houston

A. G. Rud Washington State University

Patricia Sánchez University of University of Texas, San Antonio Janelle Scott University of California, Berkeley

Jack Schneider College of the Holy Cross

Noah Sobe Loyola University

Nelly P. Stromquist University of Maryland

Benjamin Superfine University of Illinois, Chicago

Sherman Dorn

Arizona State University

Adai Tefera Virginia Commonwealth University

Tina Trujillo University of California, Berkeley

Federico R. Waitoller University of Illinois, Chicago

Larisa Warhol

University of Connecticut

John Weathers University of Colorado, Colorado Springs

Kevin Welner University of Colorado, Boulder

Terrence G. Wiley Center for Applied Linguistics

John Willinsky

Stanford University

Jennifer R. Wolgemuth University of South Florida

Kyo Yamashiro Claremont Graduate University 


\section{archivos analíticos de políticas educativas consejo editorial}

Editor Consultor: Gustavo E. Fischman (Arizona State University)

Editores Asociados: Armando Alcántara Santuario (Universidad Nacional Autónoma de México), Jason Beech (Universidad de San Andrés), Angelica Buendia (Metropolitan Autonomous University, México), Ezequiel Gomez Caride (Pontificia Universidad Católica Argentina), Antonio Luzon (Universidad de Granada), José Luis Ramírez

(Universidad de Sonora, Mexico)

\section{Claudio Almonacid \\ Universidad Metropolitana de Ciencias de la Educación, Chile Miguel Ángel Arias Ortega \\ Universidad Autónoma de la \\ Ciudad de México \\ Xavier Besalú Costa \\ Universitat de Girona, España}

Xavier Bonal Sarro Universidad Autónoma de Barcelona, España

Antonio Bolívar Boitia

Universidad de Granada, España

José Joaquín Brunner Universidad

Diego Portales, Chile

Damián Canales Sánchez

Instituto Nacional para la

Evaluación de la Educación, México

Gabriela de la Cruz Flores

Universidad Nacional Autónoma de México

Marco Antonio Delgado Fuentes Universidad Iberoamericana,

México

Inés Dussel, DIE-CINVESTAV, México

Pedro Flores Crespo Universidad Iberoamericana, México

Ana María García de Fanelli

Centro de Estudios de Estado y

Sociedad (CEDES) CONICET,

Argentina
Juan Carlos González Faraco

Universidad de Huelva, España

María Clemente Linuesa

Universidad de Salamanca, España

Jaume Martínez Bonafé

Universitat de València, España

Alejandro Márquez Jiménez Instituto de Investigaciones sobre la Universidad y la Educación, UNAM, México

María Guadalupe Olivier Tellez, Universidad Pedagógica Nacional, México

Miguel Pereyra Universidad de Granada, España

Mónica Pini Universidad Nacional de San Martín, Argentina

Omar Orlando Pulido Chaves

Instituto para la Investigación Educativa y el Desarrollo Pedagógico (IDEP)

José Luis Ramírez Romero

Universidad Autónoma de Sonora, México

Paula Razquin Universidad de San Andrés, Argentina

José Ignacio Rivas Flores

Universidad de Málaga, España
Miriam Rodríguez Vargas

Universidad Autónoma de

Tamaulipas, México

José Gregorio Rodríguez

Universidad Nacional de

Colombia, Colombia

Mario Rueda Beltrán Instituto

de Investigaciones sobre la

Universidad y la Educación, UNAM, México

José Luis San Fabián Maroto

Universidad de Oviedo,

España

Jurjo Torres Santomé,

Universidad de la Coruña, España

Yengny Marisol Silva Laya

Universidad Iberoamericana, México

Juan Carlos Tedesco

Universidad Nacional de San

Martín, Argentina

Ernesto Treviño Ronzón

Universidad Veracruzana, México

Ernesto Treviño Villarreal

Universidad Diego Portales

Santiago, Chile

Antoni Verger Planells

Universidad Autónoma de

Barcelona, España

Catalina Wainerman

Universidad de San Andrés, Argentina

Juan Carlos Yáñez Velazco

Universidad de Colima, México 


\section{arquivos analíticos de políticas educativas conselho editorial}

Editor Executivo: Gustavo E. Fischman (Arizona State University)

Editoras Associadas: Geovana Mendonça Lunardi Mendes (Universidade do Estado de Santa Catarina), Marcia Pletsch, Sandra Regina Sales (Universidade Federal Rural do Rio de Janeiro)

\author{
Almerindo Afonso \\ Universidade do Minho \\ Portugal
}

Rosanna Maria Barros Sá

Universidade do Algarve

Portugal

\section{Maria Helena Bonilla}

Universidade Federal da Bahia

Brasil

Rosa Maria Bueno Fischer Universidade Federal do Rio Grande do Sul, Brasil

\section{Alice Casimiro Lopes \\ Universidade do Estado do Rio de \\ Janeiro, Brasil}

Suzana Feldens Schwertner

Centro Universitário Univates

Brasil

Flávia Miller Naethe Motta

Universidade Federal Rural do Rio de

Janeiro, Brasil
Alexandre Fernandez Vaz

Universidade Federal de Santa

Catarina, Brasil

Regina Célia Linhares Hostins

Universidade do Vale do Itajaí,

Brasil

Alfredo Macedo Gomes

Universidade Federal de Pernambuco

Brasil

Jefferson Mainardes

Universidade Estadual de Ponta

Grossa, Brasil

Jader Janer Moreira Lopes

Universidade Federal Fluminense e

Universidade Federal de Juiz de Fora,

Brasil

Debora Nunes

Universidade Federal do Rio Grande do Norte, Brasil

Alda Junqueira Marin

Pontifícia Universidade Católica de

São Paulo, Brasil

Dalila Andrade Oliveira

Universidade Federal de Minas

Gerais, Brasil
José Augusto Pacheco

Universidade do Minho, Portugal

Jane Paiva

Universidade do Estado do Rio de

Janeiro, Brasil

Paulo Alberto Santos Vieira

Universidade do Estado de Mato

Grosso, Brasil

Fabiany de Cássia Tavares Silva Universidade Federal do Mato

Grosso do Sul, Brasil

António Teodoro

Universidade Lusófona

Portugal

Lílian do Valle

Universidade do Estado do Rio de Janeiro, Brasil

\section{Alfredo Veiga-Neto}

Universidade Federal do Rio

Grande do Sul, Brasil 